\title{
Mediation Effect of Knowledge Management Enablers on the Relationship between Organizational Characteristics and Entrepreneurial Orientation
}

\author{
Shathees Baskaran \\ Universiti Teknologi Malaysia, Malaysia
}

\begin{abstract}
The main aim of this study is to investigate the mediating effect of knowledge management enablers between the organizational characteristics and entrepreneurial orientation of employees. The study considered three constructs, namely: Knowledge management enablers, organizational characteristics and entrepreneurial orientation, to formulate the framework for this research. A quantitative approach was adopted in the study. Data were collected through a web-based online survey. The population of the survey was estimated to be around 300 employees from three cement manufacturing organizations in the state of Johor, Malaysia. A 70.4 per cent response rate was achieved. Five hypotheses were formulated and tested in the study. A simple multiple regression was used to analyse the data. All five hypotheses were supported, confirming that there is a partial mediation by the knowledge management enablers, as well as by the corresponding dimensions between organizational characteristics and entrepreneurial orientation. In addition, the implications of this study are also discussed, apart from the avenues for future research in the area of entrepreneurial orientation.
\end{abstract}

Keywords: entrepreneurial orientation; knowledge management enablers; organizational characteristics

JEL classification: L26, D83, D23 


\section{Introduction}

Knowledge has been an important consideration for organizational success for a very long time. Grant (1996) and Foss and Pedersen (2002) highlighted that the attainment of a sustainable competitive advantage in a dynamic economy requires knowledge, which still remains a critical organizational resource. Therefore, the efficient management of knowledge, as an organization's strategic resource, is critical for organizational success (Ipe 2003). It is proven by the previous literature on management, which has seen a boom in dealing with organizational knowledge as an intangible dimension of organizations (Von Krogh et al. 2001). Liao et al. (2007) explained that in order for an organization to learn new techniques, develop core competencies, solve problems and evaluate new situations, knowledge remains an important resource. In the past, knowledge was perceived as a value adding component for the organization. However, such a perception has changed over the time and in today's context, knowledge has transformed into a necessity for organizations to remain competitive and steadfast against their competitors. Crossan et al. (1999) indicated that the accumulation of knowledge and the institutionalization of individual practices led to organizational learning by integrating both employees and also entrepreneurship. The organizational ability to create, utilize and develop knowledge-based assets is said to be the magic formula for the success of many organizations (Hill et al. 2002; Morrison 2001); since knowledge is a source of growth which reflects organizational performance (March and Sutton 1997).

According to Earl (2001), knowledge management has been recognized as being central to product and process innovations, executive decision making, and organizational adaptation and renewal. The past literature reveals that there is a common understanding about the term "knowledge". In a wider context, knowledge is defined as truths and beliefs (Nonaka and Takeuchi 1995; Wiig 1994) and imbuing formatted data and information (Fahey and Prusak 1998; Raisinghani 2000), which is validated through testing to confirm its proof (Liebeskind 1996) that can be communicated or shared (Allee 1997), and is generated through the capacity for effective action (Sveiby 1997) and also past experiences (Allee 1997; Leonard and Sensiper 1998; Wijnhoven 1998). Traditionally, knowledge recognition and articulation have been the emphasis of knowledge management. However, Sabherwal and BeccerraFernandez (2003) posited that the management of important tacit knowledge is also equally crucial for organizational survival. Nevertheless, Nonaka (1991) claimed that knowledge includes explicit knowledge (that is built up from data and information from the domain of an information system) and tacit knowledge (that resides in the minds of individuals within the organization, normally as skills and competences). In addition, entrepreneurship, analysed from a knowledgebased perspective as an extension of the Resource-based View (RBV) of the firm, proposes that the development of knowledge can underpin the growth of the organization through entrepreneurship (Guadamillas et al. 2008). Nevertheless, most organizations which possess explicit and tacit knowledge do not gain the utmost benefit from this knowledge, especially when an effective set of knowledge management enablers are absent. The possession of knowledge alone will not help an organization to utilize the information unless it provides sufficient and suitable enablers that can encourage its employ- 
ees to communicate the information that is available. The availability of knowledge management enablers will initiate information exchanges across the entire organization. Efficient knowledge management has been proven to have a significant association with an organization and its performance (Aliyu 2016).

However, the literature claims that many organizations are confused when they attempt to deploy knowledge and also any related efforts (Junnarkar 1997). Some organizations tend to invest heavily in information technology as a means of knowledge management (Hansen and Oetinger 2001). Yet, an underlying question to be addressed by the organization is how to understand the enablers of knowledge management which can make its employees better informed when making business decisions and initiating necessary actions. According to Chan and Chau (2005), knowledge management enablers refer to the influencing factors which can facilitate knowledge management activities, including codification and knowledge sharing among employees. This claim is in line with Lin (2007), indicating that individual factors and also organizational factors, on top of technological factors, are the core enablers of knowledge sharing. The literature has addressed a variety of knowledge management enablers over the last two decades (LeonardBarton 1995; Ichijo et al. 1998; Sawhney and Prandelli 2000). Generally, the knowledge management enablers considered by the literature range from a single factor (Pentland 1995) to as many as ten factors (Nevis et al.1995). However, there are no conclusive findings about which knowledge management enablers influence an organization's entrepreneurial orientation and which are more prominent, while considering that different knowl- edge management enablers can exist in each organization.

\section{Literature Review}

\section{Knowledge Management Enablers}

When an organization is confronted with a competitive business environment or a new business phenomenon, they always look for new management techniques to guide their business operations. Organizations believe that knowledge management could be one of the areas needing attention when dealing with such situations. Madhavan and Grover (1998) posited that in order to create and develop new insights and capabilities, an organization should facilitate communication and also the exchange of knowledge through effective knowledge management.

Early researchers such as Walsh and Ungson (1991) indicated that individuals, culture, structure, transformation, ecology, and external archives are important enablers of knowledge management. However, over the years, this list of knowledge enablers was further expanded with the addition of several other factors such as culture and strategy, technology, organizational learning and measurement (Pan and Scarbrough 1998). This list of knowledge management enablers continues to expand. For instance, Gold et al. (2001) adopted a three factors approach, by considering technology, culture and structure as knowledge management enablers, in their attempt to investigate knowledge management's capabilities and organizational effectiveness through data collected from senior executives. The study indicated there was strong evidence that knowledge management enablers influenced the capability, and hence improved the organizational effective- 
ness. The sharing of knowledge is not a natural act (Davenport and Prusak 1998). Jordan and Jones (1997) claimed that both tacit and explicit knowledge must be managed simultaneously in order to obtain greater results. Laupase (2003) investigated this premise in the Australian environment; that study utilized a case study approach to explore the conversion of tacit knowledge to organizational explicit knowledge. Laupase (2003) investigated three knowledge management enablers, namely, culture, organizational structure and information technology. The study provided evidence that organizations perceive culture and organizational structure as their priorities in converting tacit knowledge into explicit knowledge. However, it is claimed that incentives or exchange mechanisms are needed in order to share the knowledge that is embodied in the minds of employees. A further study investigating the relationship between organizational elements and the performance of knowledge transfers in the public sector was undertaken by SyedIkhsan and Rowland (2004). That study used five factors as knowledge management enablers: Organizational structure, organizational culture, technology, people/human resources and political directives. The study suggested that one of the knowledge management enablers (i.e. organizational structure) needed further research. A follow-up study by Ngoc (2005) among Vietnamese IT companies considered communal culture, organizational communication systems, transformational leadership, and information technology as essential knowledge management enablers. The results indicated that all of these knowledge management enablers were positively influencing the sharing of knowledge.

A number of knowledge management enablers have been studied in the past, and many of them overlap (Von Krogh et al.
2000; Malhotra and Majchrzak 2004; Baskerville and Dulipovici 2006). The comparative analysis of prior studies regarding knowledge management enablers indicates an important observation. There is no common or generic set of knowledge management enablers. However, it is important that knowledge management enablers are recognized in a comprehensive and unified manner (Holsapple and Joshi 1999). On this note, Pan and Scarbrough (1998) indicate that knowledge management enablers can be viewed from a socio-technical perspective, according to a socio-technical theory. While the attributes of people and their relationships and organizational structure can be represented in a social perspective, the technical perspective deals with technology's requirements for transforming inputs to outputs (Bostrom and Heinen 1977). The review of the literature provided some directions into the knowledge management enablers' domain. Generally, knowledge management enablers converge into three main common dimensions, in line with socio-technical perspectives. They are technology, structure and culture.

\section{Technology}

Eliminating communication boundaries to encourage a seamless flow of information is important to improve the operational efficiency. Additionally, removing this obstacle is also essential to make employees behave more entrepreneurially when deriving business decisions. Interaction among the different parts of the organization is one of the important elements for achieving corporatewide objectives. Several researchers (e.g. Leonard-Barton 1995; Grant 1996; Teece 1998; Alavi and Leidner 2001) indicated that linking organizational information and knowledge integration requires an information technology infrastructure. Kendall 
(1997) posited that to enable, intensify and expand the interaction among organizational members and business units, communications technology has become essential. Failing to have an appropriate platform will result in conflicts among the business units, which will be a hindrance for an organization which aspires to view each of its employees as an entrepreneur. In support of this, Davenport and Prusak (1998) claimed that technology has a role to play in an organization, as an enabler and also a contributor in the field of knowledge management through knowledge creation (Gold et al. 2001).

Lee and Choi (2003) defined technology as the presence of information technology support within the organization. Technology presence is concerned with the ability of the technology to act as a platform which supports the search for knowledge, the communication of the knowledge, and collaboration and collaborative learning (Ngoc 2005). Effective knowledge management can be done thorough various communication technologies and channels, such as email, video conferencing and many more. However, in an organization that expects its employees to act with an entrepreneurial mindset, a technology infrastructure which includes information technology and its capabilities (Raven and Prasser 1996; Zack 1999), and decision aiding technology, which increases the capacity of an employee, organization or team to develop solutions and alternatives (Kendall 1997; Ngoc 2005) such as an information database, decision support system and or expert system which can store and retrieve large amounts of existing and new information, are of paramount importance in facilitating an effective decision-making process (Song et al. 2001). The availability of information communication technology, according to Marwick (2001), eliminates communication constraints, increases the range and depth of access to the stored information and makes knowledge sharing more rapid and convenient. This is certainly critical in an organization's attempt to instil an entrepreneurial mindset to ensure that common organizational objectives and aspirations are communicated and all its employees' entrepreneurial intentions are aligned towards the organizational goals. Information technology which decides how the knowledge is used and accessed (Leonard-Barton 1995), if managed effectively, helps an organization to realize its benefits (Ndlela and Toit 2001). In addition, according to Alavi and Leidner (2001), the existence of information technology extends an individual's reach, which goes beyond formal communication lines since it increases knowledge transfer activities in the organization. In view of that, it is observed that organizations need to have an appropriate technology platform for storing and communicating information across the organization, to enable the employees' entrepreneurial orientation. When the right technology is installed, managers believe that the information sharing will flow accordingly through the organization (Davenport 1994). However, measures should be in place to ensure that this information is not stolen or used inappropriately (Gold et al. 2001).

\section{Structure}

An organizational structure plays an important role in determining the sharing of knowledge and subsequently the behavior of the employees. Structure has been considered as one of the prominent organizational factors by many scholars (e.g. Miller 1983, 1987; Covin and Slevin 1988; Jennings and Lumpkin 1989; Slevin and Covin 1990; Naman and Slevin 1993). The structure may promote or inhibit an employee from access- 
ing and using the information on structural grounds (Hedlund 1994: Nonaka and Takeuchi 1995; O’Dell and Grayson 1998; Gold et al. 2001). As a consequence, there is a greater tendency for the organization to encourage or discourage employees' exercising their entrepreneurial orientation. It is important for the organization to design a structure which has adequate levels of flexibility in order to allow the employees to share information across the organization, with the ultimate intention of using this knowledge management as a source of entrepreneurial orientation activation. Salvato (2002), in his research on family enterprises, provided empirical evidence that there is a positive relationship between the degree of delegation and informalization and entrepreneurial orientation. Given the presence of knowledge, Hurley and Green (2005) indicated that reward, which is a critical structural factor, will influence the employees' behavior and also decision making.

McKenna (1999) defined the structure of an organization as the formal relationships and allocation of activities and resources among people. Traditionally, there are two variables that underlie the structural dimensions: Centralization and formalization (Menon and Vadarajan 1992; Tata and Prasad 2004). The influence of these structural dimensions in the organization is widely recognized (Riggins and Rhee 1999; Eppler and Sukowski 2000; Lubit 2001). Hierarchical structures that portray the decision-making authority explain the centralization dimension whereas formalization is described as the existence of written documentation, rules and procedures within the organization (Schminke et al. 2000) covering how to conduct business, which will have a strong influence on the employees' behavior. Several researchers (Kohli and Jaworski 1990;
Woodman et al. 1993) argued that centralized organizational structures tend to hinder interdepartmental communications and the sharing of ideas, which is in contrast to decentralization, which promotes a collaborative environment by emphasizing empowerment and information sharing among the employees (Hurley and Green 2005), in spite of other claims such as it may cause a chaotic situation and the duplication of effort which may arise because of decentralization (Adler 1999). On the other hand, although formalization is claimed to provide an effective means of information collection and dissemination (Segars et al. 1998), an absence of the same in an organization is perceived to be beneficial as it will allow communication among the organizational members (Jarvenpaa and Staples 2000). Although organizations which are driven by formal rules and procedures aim more towards the realization of processes than goals, and possess a lesser tendency to promote entrepreneurial orientation in the organization (Barringer and Bluedorn 1999); Stevenson and Gumpert (1985), Covin and Slevin (1991) and Zahra (1993) argue that lower levels of formalization in the organization still encourages new ideas. Burgelman (1984) stated that a lower level of formalization in an organization leads to the delegation of power to the employees and as a result, it increases the employees' chances for frequent experimentation and the creation of novel ideas while participating in making influential decisions to solve problems that they encounter around their work environment.

As claimed by Aldrich and Wiedenmayer (1993), the socio-political environment of an organization is a powerful source for creating an entrepreneurial climate in the organization. Therefore, a supportive environment, as part of the organizational 
structure, requires serious consideration by organizations in their pursuit of a climate of entrepreneurship. It is aimed at developing and nurturing entrepreneurship and entrepreneurial orientation among employees through entrepreneurial activities. Covin and Slevin (1989) suggested that an analysis of entrepreneurship should start by considering the environmental factors which shape the structure of the organization, and indicated that these factors moderate the relationship between entrepreneurial posture and firm performance.

\section{Culture}

Acknowledging the fact that culture is one of the building blocks of an organization, Demarest (1997), Davenport and Prusak (1998), and Gold et al. (2001) posited that organizational culture remains an essential element of knowledge management, and is an important enabler of knowledge management. Usually, the people within the organization, the ethics of the organization and the type of organizational structure in place shapes the organization's culture. According to Mavondo and Farrell (2004), people's behavior in the organization is shaped and controlled by the organizational culture. Various researchers (e.g. Kanter 1982 1983; Burgelman 1984; Stevenson and Gumpert 1985; Burgelman and Sayles 1986; Stuart and Abetti 1987) have studied culture as an important factor in organizations.

Organizational culture refers to a system of shared meaning held by an organization's members that distinguishes their organization from another (Schein 2004), and is driven by a set of values, beliefs, norms, and practices (Robbin 2004). Robbin (2004) further informed that it serves as a sensemaking and control mechanism for guiding and shaping employees' attitudes and behav- iors when interacting with each other. An effective organizational culture can be achieved by creating a suitable and supportive working environment (Janz and Prasarnphanich 2003). Considering that knowledge is an important element for ensuring that employees are equipped with adequate cross-functional information and also insights derived from their external environment, Leonard-Barton (1995), Davenport and Prusak (1998), Holsapple and Joshi (2000), Ndlela and Toit (2001) and Lee and Kim (2001) advised that creating a knowledgefriendly culture is critical to ensure knowledge sharing and learning among employees. It is found that a collaborative organizational culture, enhanced by a strong sense of trust, will foster more innovation among employees as well as making them committed to their tasks (Goffee and Jones 1996; DeTienne et al. 2004). Technology alone will not encourage knowledge sharing if the element of trust fails (Davenport and Prusak 1998) and an incentive system can further enhance knowledge sharing initiatives (Park 2006).

\section{Organizational Characteristics and Entrepreneurial Orientation}

Entrepreneurial orientation is known to be manifest in all product and process innovations (Ireland and Webb 2007) which involve processes, practices, and decision-making activities that lead to a new entry (Lumpkin and Dess 1996). In discovering existing and new market opportunities, it is essential for the employees in the organization to possess entrepreneurial attitudes and behavior which are critical for new ventures facilitated by the existing and new knowledge (Wiklund and Shepherd 2003). Often, the types of entrepreneurial activities that an organization pursues are influenced by its internal organizational factors (Burgelman 
1983a, b). The importance of the internal organizational dimensions in promoting entrepreneurial orientation among organizational citizens has been acknowledged by many researchers in the past (Hornsby et al. 2009; Kuratko et al. 2001; Kuratko et al. 1990).

According to Drucker (1986), entrepreneurial orientation is an innovative process in which new products and service opportunities are confirmed and created to generate greater capabilities in order to create new wealth. On the other hand, Miller (1983) stated that entrepreneurial orientation concerns the decision-making styles, methods and practices which are the essence of an entrepreneurial action. Moreover, Covin and Slevin (1989) and Lumpkin and Dess (1996) highlighted that an organization's entrepreneurial traits and entrepreneurial culture, as described by its organizational values, unique concepts and key organizational characteristics constitute its entrepreneurial orientation. This includes two aspects: A new way of doing and thinking and exploring opportunities; and organizing resources to offer a new market value. Numerous variables, including internal factors that serve as important antecedents of the entrepreneurial efforts which determine the interest in support of entrepreneurial initiatives within an organization, were investigated by past researchers. Among others, they include incentive and control systems (Sathe 1985), culture (Kanter 1985; Hisrich and Peters 1986; Brazeal and Herbert 1999), organizational structure (Covin and Slevin 1991; Naman and Slevin 1993; Dess et al. 1999), and managerial support (Stevenson and Jarillo 1989; Kuratko et al. 1993). Research reveals that entrepreneurially oriented companies tend to outperform other organizational types in volatile environments (McKee et al. 1989) and stronger adaptation during turbulent settings help an organization to perform better than conservative organizations (Bourgeois 1980; Snow and Hrebiniak 1980; Covin and Slevin 1991).

The nature of the field of entrepreneurship that focuses on environmental adaptation and opportunities' exploration (Hitt et al. 2001) has transformed the attention of organizations from being sustainably strong to being continuously innovative, realizing that the essence of entrepreneurship is creation and newness, and newness is a result of innovation (Shane and Venkataraman 2000). Fundamentally, a shift from the current state of activities to future improvements can be facilitated and accomplished by knowledge resources (Mahoney 1995). However, the views of managers and entrepreneurs in pursuing entrepreneurial efforts are shaped by the existence of appropriate organizational factors (Kuratko et al. 1990). According to Wiklund and Shepherd (2005), combining the power of any available slack in the organization and knowledge is expected to improve the level of entrepreneurial orientation in the organization. Past and current research has identified an array of organizational constructs that drive entrepreneurial orientation among employees. Entrepreneurial orientation's proponents identified management support (Damanpour 1991; Kuratko et al. 1993; Pearce et al. 1997; Hornsby et al. 2002), resource and time availability (Damanpour 1991; Stopford and BadenFuller 1994; Slevin and Covin 1997; Hornsby et al. 2002), work discretion (Sathe 1985; Jennings and Lumpkin 1989; Stopford and Baden-Fuller 1994; Hornsby et al. 1999), rewards and reinforcement (Sathe 1985; Sykes 1992; Twomey and Harris 2000; Hornsby, et al. 2002) and a supportive organizational culture (Sathe 1985; Zahra 1991; Covin and Slevin 1991; Hornsby and Naffziger 1992; 
Hornsby et al. 2002). Aside, the availability of knowledge encourages opportunity exploitation with calculated risks (Morris and Kuratko 2002). In addition, these combinations are found to embrace new problems (Baker and Nelson 2005) and discover high numbers of, and profitable, entrepreneurial opportunities (Eckhardt and Shane 2003; Wiklund and Shepherd 2005; Kor et al. 2007).

\section{Knowledge Management Enablers as Mediators}

Knowledge is central to creating an organization that performs better in an uncertain business environment, which can affect the organizational agility (Beckman 1997). The attainment of organizational effectiveness and its resulting performance creates a greater emphasis on knowledge management and knowledge sharing, as well as the mechanisms that encourage these activities. Therefore, knowledge is found to be another area that has a crucial role to play in creating the employees' entrepreneurial orientation. It entails the storing and retrieval of information quickly and easily to adjust the organizational orientation's alignment to market shifts, hence facilitating problem solving as well as decision-making processes to ultimately improve the organizational efficiency (Almeida 1996). Apart from that, the availability of knowledge and the efficient utilization of it ensure the sustainability of the organization (Elwany and Mahrous 2016). In view of that, the availability of a technological facility which administers the information gathered internally and externally is essential. Several researchers (Leonard-Barton 1995; Grant 1996; Teece 1998; Alavi and Leidner 2001) have emphasized that the availability of a suitable information technology infrastructure and applications that link the organization's information are essential for organizational knowledge's integration. The systematic storing, access, simulation and prediction of technological capabilities will help an employee to utilize this information in his/her day-to-day operations. Alavi and Leidner (2001) indicated that breaking a formal communication line and extending an individual's communication beyond such a formal environment can only be done with information technology. This breakthrough will also create a collaborative work environment regardless of the time and place, while fostering communication among all the employees.

An adequate level of knowledge is essential to assist the employees to consider cause and effect before engaging themselves in entrepreneurial activities. Acknowledging the fact that both internal and external information is crucial for entrepreneurial decision making, Leonard (1995) noted that technology helps an organization to locate a specific type of information arising from its internal and external environment, while continuously tracking the source of the information. An organization, through its employees, will be better positioned to achieve its short- and long-term objectives if the employees are equipped with the necessary level of knowledge, while also ensuring that a knowledge management enabler is in place. Nevertheless, the adoption of technology will not ensure an organization's success. Instead, userfriendly technology is important to promote the systems in the organization, while promoting the use of the system among the employees, so that their decisions are backed by an adequate level of information. Addressing the needs of the employees, as part of the technological application's development, is paramount to increase the benefit of the technological investment so that the technol- 
ogy serves the intended purpose in the organization, while fostering more entrepreneurial decision making among the employees (King 1999). According to Sathe (1985), Hisrich and Peters (1986), Sykes and Block (1989), Bird (1988), Covin and Slevin (1991), Zahra (1991), and Hornsby and Naffziger (1992), a supportive organizational culture is one of the main drivers in creating employee entrepreneurial orientation. A supportive organizational culture is expected to keep the momentum among employees, ensuring that they equip themselves with the latest developments within their industry so that they can act promptly to changes and reap the economic benefits of these changes. Moreover, according to Von Krogh (1998) and Cohen and Prusak (2001), an active knowledge sharing among employees can only be realized if trust and openness is promoted by the organization's culture. In addition to this, a collaborative work environment among the employees, with both formal and informal relationships for sharing the varying knowledge perspectives (O'Dell and Grayson 1998) will foster these knowledge sharing activities, which will instil mutual faith in each other's behavior, intentions, and abilities, while encouraging each and every one of them to reflect on their commitment to the company as a whole.

In order to foster free communication among the employees, trustworthiness plays an important role, as it empowers the employees to share their tacit and explicit knowledge and hence enhances and speeds-up the communication process (Von Krogh 1998). Although work discretion provides freedom and decision-making latitude to the employees, the readiness of the organization to tolerate failure reflects the trusting relationship between the organization and its employees, which helps to eliminate the fear of failure and deception (Nonaka 1990). In addition, the organizational structure is also another important element of the knowledge management enabler that facilitates the employees' entrepreneurial orientation (Burgelman and Sayles 1986).

Several scholars such as Creed and Miles (1996) and O’Dell and Grayson (1998) have discussed the importance of organizational structure in the knowledge sharing process in an organization. In a general context, organizational structure encompasses three main dimensions, which include centralization, formalization and performance-based reward systems. Providing a reasonable level of authority and the freedom to act freely with the minimum of necessary supervision will help employees to discover their untapped potential. For instance, according to Creed and Miles (1996), a hierarchical structure in an organization usually limits or hinders knowledge sharing and communication between employees, or between employees and their superiors. Although typically an organization puts in place written procedures for conducting its business and does not allow ignorance of the rules to be an excuse, and it will reach informal agreements to handle some situations, a certain level of flexibility may help the employees to uncover their potential to contribute to the performance achievement of the organization. O'Dell and Grayson (1998) concur with this claim, informing that flexibility shall be allowed within the organization's structure in order to promote information sharing, collaboration and communication beyond the traditional organizational boundaries. However, flexibility within an organizational structure alone will not enable the organization's citizens to practice information sharing. Inadequate motivation among employees tends to be one of the common impedi- 
ments to knowledge transfer within organizations (Szulanski 1996). An appropriate performance-based rewards system should be installed to motivate the employees to engage themselves in such practices, and hence share readily available knowledge, generate new knowledge, and actively participate in crossfunctional information and knowledge sharing (Leonard-Barton 1995; O’Dell and Grayson 1998). Neely (1998) agreed with this argument, indicating that performance-based reward systems are suitable mechanisms to foster involvement and communication among organizational members, apart from collecting, processing and disseminating information. Therefore, assimilation and continuous updating of the knowledge with relevant enablers is important to win the market place (Elwany and Mahrous 2016).

Hence, based on this discussion, the following hypotheses were formulated:
$H_{1}$ : There is a relationship between organizational characteristics and entrepreneurial orientation.

$\mathrm{H}_{2}$ : There is a mediating effect of knowledge management enablers between organizational characteristics and entrepreneurial orientation.

$H_{2 a}$ : There is a mediating effect of technology between organizational characteristics and entrepreneurial orientation.

$H_{2 b}$ : There is a mediating effect of structure between organizational characteristics and entrepreneurial orientation.

$H_{2}$ : There is a mediating effect of culture between organizational characteristics and entrepreneurial orientation.

Based on these testable hypotheses, the following conceptual framework was proposed for the research.

Figure 1. Conceptual Framework

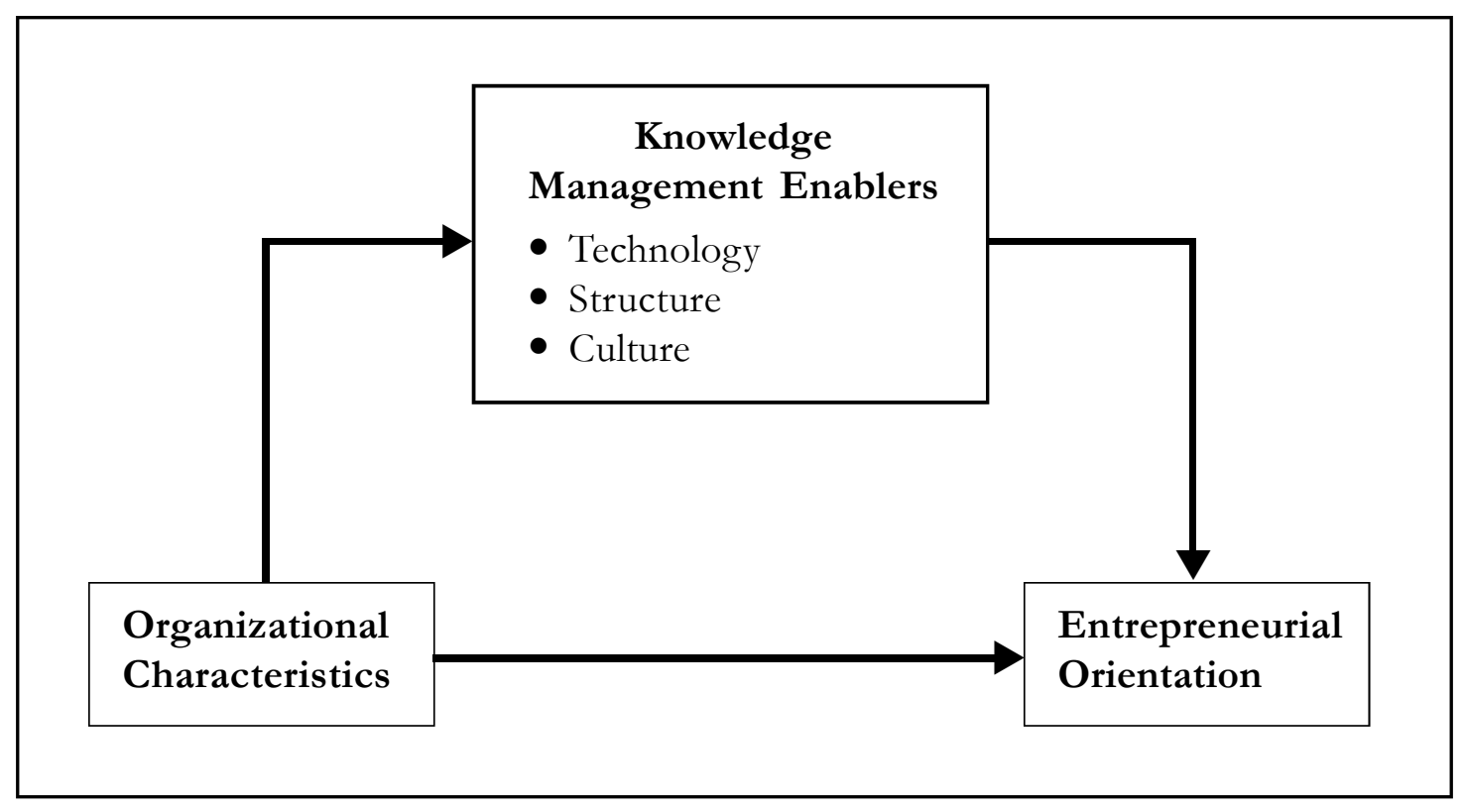




\section{Methods}

\section{Sample and Data Collection}

The target population of the study was the employees from three cement manufacturing companies in the state of Johor in Malaysia. These three cement manufacturing organizations shared a similar attribute, by acting as the grinding stations for all the other operations, which were classified as integrated operations. In order to eliminate the influence of extraneous organizations outside the state of Johor, which may operate as integrated operations, contrary to the grinding operations in the state of Johor, the geographical coverage of the respondents was limited to employees from home-based cement manufacturing organizations in the state of Johor. The population of the study was estimated to be around 300 employees. An online survey was used to distribute the questionnaires to the respondents by employing a simple random sampling method. An online survey was chosen since web surveys have a wider acceptance today (Porter and Whitcomb 2003; Dillman 2007) and therefore this approach could be expected to reach the maximum number of respondents. In order to avoid missing data, all the questions were made mandatory, as such all the responses received were usable for the analysis. Overall, the online survey consisted of 79 questions in four main areas: i) Personal and organizational information; ii) organizational characteristics; iii) entrepreneurial orientation and iv) knowledge management enablers. A follow-up was made to improve the response rate from the respondents to ensure the generalizability of the research findings (Rea and Parker 2005).

\section{Measures and Instrumentation}

The test instruments and also the corresponding measures used in this study were adapted from previous research. Organizational characteristics' construct test instruments were adopted from Hornsby et al. (1999). This construct consisted of 21 items. On the other hand, Covin and Slevin's (1989) and Seibert et al. (2001) test instruments were used to measure the entrepreneurial orientation's construct, and the total items used for this construct were 23 . In order to measure the knowledge management enabler's construct, the test instruments and measures developed by Lee and Choi (2003) were used. This construct occupied 26 items covering all three dimensions of the construct. Since behavior measurement can best be done with a five-point Likert scale (Wolfer 2007), respondents replies to the test items were designed to range from a score of 1 ("strongly disagree") to 5 ("strongly agree") for them to locate their agreeableness.

\section{Findings}

\section{Data Analysis}

After collecting data for about three months, 181 usable questionnaires were obtained. Since the questionnaire was designed as a web survey and all the test items were mandatory, no questionnaire was omitted as a result of missing data. A 70.4 per cent response rate was achieved after two waves of data collection. This response rate was sufficient to conduct further statistical analysis (Krejcie and Morgan 1970). About 70.7 per cent of the respondents were male; confirming that the nature of the industry is a male 
dominated industry. Respondents in the age range between 31 to 40 years old made up about half of the total respondents. From a functional perspective, most of the respondents that participated in this study were from the operational department (i.e. 43.1 per cent). As far as their academic background is concerned, 51.4 per cent of the respondents hold an undergraduate degree, followed by diploma holders as the second largest group. About 75 per cent of the respondents were still new to their organizations, having been with them for less than five years when the survey was undertaken.

\section{Reliability Test}

To improve the credibility of research findings, careful attention must be paid to the

Table 1. Reliability Results of Survey Instrument

\begin{tabular}{lc}
\hline \multicolumn{1}{c}{ Variable } & $\begin{array}{c}\text { Cronbach's } \\
\text { Alpha }\end{array}$ \\
\hline $\begin{array}{l}\text { Knowledge Management } \\
\text { Enabler }\end{array}$ & 0.817 \\
$\begin{array}{l}\text { Organizational } \\
\text { Characteristics }\end{array}$ & 0.730 \\
$\begin{array}{l}\text { Entrepreneurial } \\
\text { Orientation }\end{array}$ & 0.887 \\
\hline
\end{tabular}

reliability of the test instruments (Saunders et al. 2000). According to Borg and Gall (1979), it is important to ensure the clarity of the questions in the data collection process. In order to ensure the reliability of the test instruments, a reliability test was conducted for all the constructs under study and the results are reported in Table 1.

As informed by Devellis (1991), a Cronbach's alpha score of more than 0.70 is adequate to support the reliability of the test instrument and to reflect the credibility of the research findings. The results show that the test instruments have met these requirements and therefore, the findings are valid.

\section{Results of the Tests of the Hypotheses}

The research tested organizational characteristics, entrepreneurial orientation and the knowledge management enablers construct and its corresponding dimensions (i.e. technology, structure and culture). It was hypothesized that there is a relationship between organizational characteristics and entrepreneurial orientation and a mediating effect of knowledge management enablers between organizational characteristics and entrepreneurial orientation. A simple multiple regression analysis using SPSS version 19 was conducted and the following results were obtained.

Table 2. Entrepreneurial Orientation: Relationship between Organizational Characteristics and Entrepreneurial Orientation

\begin{tabular}{ccccc}
\hline Independent Variable & Standardized Beta & t-value & $\begin{array}{c}\text { Sig. (p- } \\
\text { value) }\end{array}$ & $\mathbf{R}^{2}$ \\
\hline Organizational Characteristics & 0.492 & 7.567 & 0.000 & 0.242 \\
\hline
\end{tabular}


$H_{1}$ : There is a relationship between organizational characteristics and entrepreneurial orientation

$\mathrm{H}_{1}$ Stated that there is a significant relationship between organizational characteristics and entrepreneurial orientation. Table 2 shows the result of the regression analysis.

The $\mathrm{t}$-value is 7.567 at $\mathrm{p}<0.05$. The result shows that $\mathrm{H} 1$ is supported. Hence, there is a significant relationship between organizational characteristics and entrepreneurial orientation. The strength of the relationship, which was measured by a standardized beta value (i.e. 0.492 ), provides sufficient support about the predictive ability of organizational characteristics towards entrepreneurial orientation. Therefore, it can be concluded that organizational characteristics influence entrepreneurial orientation in an organization. This significant relationship allows for further analysis to investigate the mediating effect of knowledge management enablers between organizational characteristics and entrepreneurial orientation.
$H_{2}$ : There is a mediating effect of knowledge management enablers between organizational characteristics and entrepreneurial orientation

$\mathrm{H}_{2}$ stated that there is a mediating effect of knowledge management enablers between organizational characteristics and entrepreneurial orientation. Table 3 shows the result of the regression analysis.

Following Baron and Kenny's (1986) procedure for mediation, path $a$ (organizational characteristics to knowledge management enablers) was assessed with a regression analysis. The result indicated that path $a$ was significant at a t-value of 7.418 and $p<$ 0.05 , which supported $(\beta=0.485, \mathrm{p}<$ 0.001). Then the second step measuring path $b$ was undertaken for knowledge management enablers and entrepreneurial orientation. The results obtained were significant at a $t$-value of 6.569 and $\mathrm{p}<0.05$, which supported path $b(\beta=0.441, \mathrm{p}<0.001)$. Path $c$ (organizational characteristics and entrepreneurial orientation) was measured as the third step and

\section{Table 3. Knowledge Management Enablers}

Mediating Effect of Knowledge Management Enablers between Organizational Characteristics and Entrepreneurial Orientation

\begin{tabular}{lrrrr}
\hline \multicolumn{1}{c}{ Relationships } & $\begin{array}{c}\text { Standardized } \\
\text { Beta }\end{array}$ & t-value & $\begin{array}{c}\text { Sig. } \\
\text { (p-value) }\end{array}$ & $\mathbf{R}^{2}$ \\
\hline OC and KME & 0.485 & 7.418 & 0.000 & 0.235 \\
KME and EO & 0.441 & 6.569 & 0.000 & 0.194 \\
OC and EO & 0.492 & 7.567 & 0.000 & 0.242 \\
OC and KME Predicting EO & & & & 0.296 \\
OC & 0.364 & 5.064 & 0.000 & \\
KME & 0.264 & 3.673 & 0.000 & \\
\hline
\end{tabular}


the result was significant at a t-value of 7.567 and $\mathrm{p}<0.05$ and supported path $\mathrm{c}(\beta=$ $0.492, \mathrm{p}<0.001)$. The first three steps were significant. Therefore, step four was performed to test for full mediation, partial mediation or no mediation. The fourth requirement for mediation, path $c$ was assessed through a regression analysis (where paths $a$ and $b$ were controlled). The results obtained indicated that there is still a significant relationship ( $\mathrm{t}$-value of 5.064 and $\mathrm{p}<0.05$ ), however with a reduced standardized beta value $(\beta=0.364, p<0.001)$. Given the statistical findings, it was concluded that there is a partial mediation of the relationship. Therefore, Hypothesis $\mathrm{H}_{2}$ is supported, indicating that there is a partial mediation effect of knowledge management enablers between organizational characteristics and entrepreneurial orientation.

$H_{2 a}$ : There is a mediating effect of technology between organizational characteristics and entrepreneurial orientation.

$\mathrm{H}_{2 \mathrm{a}}$ stated that there is a mediating effect of technology between organizational characteristics and entrepreneurial orientation. Table 4 shows the result of the regression analysis.
Path $a$ (organizational characteristics to technology) was assessed with a regression analysis. The result indicated that path $a$ was significant at a t-value of 4.719 and $\mathrm{p}<0.05$, which supported $(\beta=0.333, \mathrm{p}<0.001)$. Then the second step, measuring path $b$, was undertaken for technology and entrepreneurial orientation. The results obtained were significant at a t-value of 4.870 and $p<0.05$, which supported path $b(\beta=0.342, \mathrm{p}<$ 0.001). Path $c$ (organizational characteristics and entrepreneurial orientation) was measured in the third step and the result was significant at a t-value of 7.567 and $p<0.05$ and supported path $c(\beta=0.492, \mathrm{p}<0.001)$. The first three steps were significant, so step four was performed to test for full mediation, partial mediation or no mediation. The fourth requirement for mediation, path $c$, was assessed through a regression analysis (where paths $a$ and $b$ were controlled). The results obtained indicated that there is still a significant relationship (t-value of 6.302 and $\mathrm{p}<$ $0.05)$, however with a reduced standardized beta value $(\beta=0.426, \mathrm{p}<0.001)$. Given the statistical findings, it was concluded that there is a partial mediation in the relationship. Therefore, Hypothesis $\mathrm{H}_{2 \mathrm{a}}$ is supported, in-

\section{Table 5. Structure}

Mediating Effect of Structure between Organizational Characteristics and Entrepreneurial Orientation

\begin{tabular}{lcccc}
\hline \multicolumn{1}{c}{ Relationships } & $\begin{array}{c}\text { Standardized } \\
\text { Beta }\end{array}$ & t-value & $\begin{array}{c}\text { Sig. } \\
\text { (p-value) }\end{array}$ & $\mathbf{R}^{2}$ \\
\hline OC and Structure & 0.438 & 6.511 & 0.000 & 0.191 \\
Structure and EO & 0.379 & 5.480 & 0.000 & 0.144 \\
OC and EO & 0.492 & 7.567 & 0.000 & 0.242 \\
OC and Structure Predicting EO & & & & 0.275 \\
OC & 0.404 & 5.690 & 0.000 & \\
Structure & 0.202 & 2.852 & 0.005 & \\
\hline
\end{tabular}


dicating that there is a partial mediating effect of technology between organizational characteristics and entrepreneurial orientation.

\section{$H_{2 b}:$ There is a mediating effect of structure between organizational characteristics and entrepreneur- ial orientation}

$\mathrm{H}_{2 \mathrm{~b}}$ stated that there is a mediating effect of structure between organizational characteristics and entrepreneurial orientation. Table 5 shows the result of the regression analysis.

Again, following Baron and Kenny (1986) procedure for mediation, path $a$ (organizational characteristics to structure) was assessed with a regression analysis. The result indicated that path $a$ was significant (tvalue of 6.511 and $p<0.05)$ and supported $(\beta=0.438, \mathrm{p}<0.001)$. Then the second step measuring path $b$ was undertaken for structure and entrepreneurial orientation. The results obtained supported path $b(\beta=0.379$, $\mathrm{p}<0.001)$ and was significant ( $\mathrm{t}$-value of $5.480, \mathrm{p}<0.05$ ). Path $c$ (organizational characteristics and entrepreneurial orientation) was measured as the third step, and the re- sult was significant and supported path $c(\beta=$ $0.492, \mathrm{p}<0.001)$. Finally, the fourth requirement for mediation, path $c$ was assessed through a regression analysis (where paths $a$ and $b$ were controlled). The results obtained indicated that there is still a significant relationship (t-value of 5.690, $\mathrm{p}<0.05$ ), however with a reduced standardized beta value $(\beta=0.404, p<0.001)$. It was concluded that partial mediation exists in the relationship. Therefore, Hypothesis $\mathrm{H}_{2 \mathrm{~b}}$ is supported indicating that the relationship between organizational characteristics and entrepreneurial orientation is partly mediated by structure.

\section{$H_{2 i}$ : There is a mediating effect of culture between organizational characteristics and entrepreneur- ial orientation}

$\mathrm{H}_{2 \mathrm{c}}$ stated that there is a mediating effect of culture between organizational characteristics and entrepreneurial orientation. Table 6 shows the result of the regression analysis.

Following the procedure for mediation, path a (organizational characteristics to culture) was assessed with a regression analysis. The result indicated that path $a$ was signifi-

\section{Table 6. Culture}

Mediating Effect of Technology between Organizational Characteristics and Entrepreneurial Orientation

\begin{tabular}{lcccc}
\hline \multicolumn{1}{c}{ Relationships } & $\begin{array}{c}\text { Standardized } \\
\text { Beta }\end{array}$ & t-value & $\begin{array}{c}\text { Sig. } \\
\text { (p-value })\end{array}$ & $\mathbf{R}^{2}$ \\
\hline OC and Culture & 0.225 & 3.090 & 0.002 & 0.051 \\
Culture and EO & 0.200 & 2.729 & 0.007 & 0.040 \\
OC and EO & 0.492 & 7.567 & 0.000 & 0.242 \\
OC and Culture Predicting EO & & & & 0.251 \\
OC & 0.471 & 7.076 & 0.000 & \\
Culture & 0.094 & 1.409 & 0.161 & \\
\hline
\end{tabular}


cant $(\mathrm{t}$-value $=3.090, \mathrm{p}<0.05)$ and supported $(\beta=0.225, \mathrm{p}<0.001)$. The second step measuring path $b$ was undertaken for culture and entrepreneurial orientation and the results obtained supported path $b(\beta=$ $0.200, \mathrm{p}<0.001)$ and were significant $(\mathrm{t}-$ value $=2.729, \mathrm{p}<0.05$ ). Path $c$ (organizational characteristics and entrepreneurial orientation) was measured as the third step and the result was significant and supported path $c(\beta=0.492, \mathrm{p}<0.001)$. Finally, the fourth requirement for mediation, path $c$ was assessed through a regression analysis (where paths $a$ and $b$ were controlled). The results obtained indicated that there is still a significant relationship $(\mathrm{t}$-value $=7.076, \mathrm{p}<0.05)$, however with a reduced standardized beta value $(\beta=0.471, \mathrm{p}<0.001)$. This provided evidence of a partial mediation in the relationship. Therefore, Hypothesis $\mathrm{H} 2 \mathrm{c}$ is also supported, indicating that structure mediates the relationship between organizational characteristics and entrepreneurial orientation.

\section{Discussions}

One hypothesis was tested to investigate the relationship between organizational characteristics and entrepreneurial orientation and four hypotheses were tested to investigate the mediating effect of knowledge management enablers and their corresponding dimensions between organizational characteristics and entrepreneurial orientation. Based on the statistical analysis, all the hypotheses (i.e. $\mathrm{H}_{1}, \mathrm{H}_{2}, \mathrm{H}_{2 \mathrm{a}}, \mathrm{H}_{2 \mathrm{~b}}$ and $\mathrm{H}_{2 \mathrm{c}}$ ) were supported. This explains that organizational characteristics and entrepreneurial orientation are partially mediated by the knowledge management enablers construct and its dimensions of technology, structure and culture. Elwany and Mahrous (2016) indicated that an organization that has enough knowledge about its environment will be able to minimize the organization's environmental impact. This is in line with several past studies which investigated the impact of technology on organizational survival and sustainability. Knowledge management processes rely heavily on technology, which requires investment by the organization (Iqbal Shaikh and Aktharsha 2016). Environment remains an important element in determining an organization's performance (Zaheer et al. 2010), and technology is considered to be an important component of that environment, for coping with uncertainties and ensuring organizational survival (Jeong et al. 2006). Further support for our result was found in Kropp et al. (2006), who confirmed that the environmental factor does influence entrepreneurial orientation. Zahra and Nielsen (2002) posited that technology is able to improve coordination across groups, as it encourages employees to interact among themselves, as well as to approach and solve issues in a collaborative manner. Similar findings were reported by Kahn (1996), that technology helps a firm to create a better alignment between its internal and external forces. It was also found that structure mediates the relationship between organizational characteristics and entrepreneurial orientation. Instead of a full mediation, only a partial mediation was observed through the statistical results. Therefore, it was concluded that the organizational structure supports the entrepreneurial orientation's activation in the organization. Similar findings were reported in the past literature. A structure which defines the allocation of responsibilities and also the level of authority in the organization (Greenberg and Baron 1997) provides a greater and diffused flow of information in the organization for the activation of entrepreneurial orientation. The statistical results provided evidence of the mediation 
by culture between organizational characteristics and entrepreneurial orientation. However, there was no evidence of a full mediation. The critical role of culture in cultivating and shaping entrepreneurial orientation in the organization was well emphasized by Kanter (1985). Waseem Bari et al (2016) highlighted that knowledge culture and knowledge management practices increases the rate of innovation, enable organizations to enhance their market segments and improve their service quality and operational effectiveness, which requires an entrepreneurial mindset among the employees. Generally, entrepreneurial culture is focused on the creation of new possibilities facilitated by various elements such as innovations, the propensity for risk taking and also pro-active behavior by accepting as well as managing the forces for change. Various researchers (Martin 1992; West and Berthon 1997; Pennington 2001) have addressed that the behavior of individuals is influence by the culture that is being practiced in the organization. Deal and Kennedy (2000) explained culture as the ways and means that things are taken up and completed in the organization. Iqbal Shaikh and Aktharsha (2016) highlighted that a culture of connectivity and collaboration between the members of the team, via mobile and social technology, helps the organization to improve performance. Similar findings on the mediating effect of culture among other knowledge management enablers were also reported in a recent study by Elwany and Mahrous (2016). Often, management engages in entrepreneurial orientation by committing to it on a broader range in the organization. However, this transformation requires support from the entire organization, with active engagement from its organizational citizens. Robinson (2001) highlighted that entrepreneurial orientation will become a culture leading towards organizational renewal only if such efforts are nurtured through behavior and practices. Therefore, the most important element that can affect the effectiveness of knowledge management is the culture requiring the organization to foster knowledge management and develop a sharing culture in the organization (Rahimi Rad et al. 2016). In spite of being pro-active and innovative, it is crucial that employees are experimenting their entrepreneurial attempts, without fear of reprisal, especially when their attempts do not produce the expected outcomes. Such a culture is found to promote continuous knowledge sharing in order to undertake risky attempts (Niaz Azari and Amooei 2008). Further support was provided by Deshpande et al. (2004) and Baughn et al. (2006), who all found that the cultural factor, which includes organizational culture, enhances the entrepreneurial orientation leading towards business success in the organization. In addition to this, Nguyen et al. (2007) explained that the absence of a strong entrepreneurial culture indicates the presence of a risk avoidance attitude, since culture may positively or negatively affect the willingness to take risks and hence to make business decisions. In addition, organizational culture could create the proper climate to encourage entrepreneurial behavior among employees, and this is in alignment with the studies by Lumpkin and Dess (2001), Ireland et al. (2006) and Hughes and Morgan (2007). Therefore, it is evident that the emergence of knowledge management is important to ensure organizational performance (Iqbal Shaikh and Aktharsha 2016). 


\section{Conclusion}

To summarize, entrepreneurial behavior can exist at all levels of an organization. However, the activation of entrepreneurial intention and the exercise of entrepreneurial behavior are subject to the availability of knowledge management enablers, coupled with conducive organizational characteristics that facilitate such endeavors among the employees. Based on the empirical evidence provided in this research, it can be concluded that all the various aspects of the knowledge management enablers are crucial in order to create an entrepreneurially oriented workforce. This research provided several significant implications contributing towards both the theory and also practice. More importantly, this study helped to extend the study of knowledge management enablers, organizational characteristics and entrepreneurial orientation into a new setting and unchartered contexts. In particular, the inclusion of a knowledge management enabler as a mediator between organizational characteristics and also entrepreneurial orientation breaks new ground in the fields of both organizational characteristics and also entrepreneurial orientation. These results can also be used by organizations as a foundation for setting up an entrepreneurial orientation climate, while paying adequate attention to all the related contextual factors within their organization.

\section{Suggestion for Future Research}

Despite the findings reported in the study, several suggestions are offered for future research. The following are suggested as future avenues for research considering the framework and findings of this study: (1) It is suggested for future research to look at unaccounted variables within the study of knowledge management enablers, organizational characteristics and also entrepreneurial orientation, considering the richness of the research field and also its interrelationship with various constructs within an organizational context, so a more predictive model of this phenomenon may yield more unexplored findings; (2) triangulation of the empirical responses with qualitative research to understand the relationship between the constructs under study and also to provide more conclusive findings; (3) the model can also be tested across various settings to ensure the generalizability of the findings; and (4) to explore the possibilities of considering a moderating variable to develop a more predictive model in order to generate more unique outcomes and to improve the validity of the existing findings in the literature.

\section{References}

Adler, P. S. 1999. Building better bureaucracies. Academy of Management Executive 13 (4): 36-47.

Alavi, M., and D. Leidner. 2001. Review: Knowledge management and knowledge management systems: Conceptual foundations and research issues. MIS Quarterly 25 (1): 107-136.

Aldrich, H., and G. Wiedenmayer. 1993. From traits to rates: An ecological perspective on organizational foundings. Advances in Entrepreneurship, Firm Emergence and Growth 1: 145-95. 
Aliyu, M. S. 2016. Influence of knowledge management on performance in small manufacturing firms. International Journal of Business, Economics and Law 8 (2): 63-67.

Allee, V. 1997. Knowledge Evolution: Expanding Organizational Intelligence. Boston, MA: Butterworth-Heinemann.

Almeida, P. 1996. Knowledge sourcing by foreign multinationals: Patent citation analysis in the U.S. semiconductor industry. Strategic Management Journal 17 (Winter Special Issue): 166-165.

Baker, T., and R. E. Nelson. 2005. Creating something from nothing: Resource construction through entrepreneurial bricolage. Administrative Science Quarterly 50 (3): 329-366.

Baron, R. M., and D. A. Kenny. 1986. The moderator-mediator variable distinction in social psychological research: Conceptual, strategic and statistical considerations. Journal of Personality and Social Psychology 51 (6): 1173-1182.

Barringer, B. R., and A. C. Bluedorn. 1999. The relationship between corporate entrepreneurship and strategic management. Strategic Management Journal 20 (5): 421-444.

Baskerville, R., and A. Dulipovici. 2006. The theoretical foundations of knowledge management. Knowledge Management Research and Practice 4 (2): 83-105.

Baughn, C. C., J. S. R. Cao, L. L. M. Le, V. A. Lim, and K. E. Neupert. 2006. Normative, social and cognitive predictors of entrepreneurial interest in China, Vietnam and the Philippines. Journal of Developmental Entrepreneurship 11 (1): 57-77.

Beckman, T. 1997. A Methodology for Knowledge management. International Association of Science and Technology for Development (IASTED) AI and Soft Computing Conference. Banff, Canada.

Bird, B. 1988. Implementing entrepreneurial ideas: The case for intention. Academy of Management Review 13 (3): 442-453.

Borg, W. R., and M. D. Gall. 1979. Educational Research (3rd ed.) White Plains, NY: Longman.

Bostrom, R., and J. Heinen. 1977. MIS problems and failures: A socio-technical perspective. MIS Quarterly 1 (3): 17-32.

Bourgeois, L. 1980. Strategy and environment: A conceptual integration. Academy of Management Review 5 (1): 25-39.

Brazeal, D., and T. Herbert. 1999. The genesis of entrepreneurship. Entrepreneurship: Theory and Practice 22 (3): 29-45.

Burgelman, R. A. 1983a. Corporate entrepreneurship and strategic management: Insights from a process study. Management Science 29 (12): 1349-1364.

Burgelman, R. A. 1983b. A process model of internal corporate venturing in the diversified major firm. Administrative Science Quarterly 28 (2): 223-244.

Burgelman, R. A. 1984. Designs for corporate entrepreneurship. California Management Review 26 (2): 154166.

Burgelman, R. A., and L. R. Sayles. 1986. Inside Corporate Innovation: Strategy, Structure and Managerial Skills. New York: Free Press

Chan, I., and P. Y. K. Chau. 2005. Getting knowledge management right: Lessons from failure. The International Journal Knowledge Management 1 (3): 40-54.

Cohen, D., and L. Prusak. 2001. In Good Company, How Social Capital Makes Organizations Work. Harvard Business School Press. 
Covin, J. G., and D. P. Slevin. 1988. The influence of organization structure on the utility of an entrepreneurial top management style. Journal of Management Studies 25 (3): 217-234.

Covin, J. G., and D. P. Slevin. 1989. Strategic management of small firms in hostile and benign environments. Strategic Management Journal 10 (1): 75-87.

Covin, J. G., and D. P. Slevin. 1991. A conceptual model of entrepreneurship as firm behavior. Entrepreneurship: Theory and Practice 16 (1): 7-24.

Crant, M. J. 1996. The proactive personality scale as a predictor of entrepreneurial intentions. Journal of Small Business Management 34 (3): 42-49.

Creed, W. E., and R. E. Miles. 1996. Trust in organizations: A conceptual framework linking organizational forms, managerial philosophies, and the opportunity costs of controls. In Kramer, R. M., and T. R. Tyler (Ed.), Trust In Organizations: Frontiers of Theory and Research: 16-38. Thousand Oaks, CA: Sage.

Crossan, M., H. Lane, and R. White.1999. An organizational learning framework: From intuition to institution. Academy of Management Review 24: 522-537.

Damanpour, F. 1991. Organizational innovation: A meta-analysis of effects of determinant and moderators. Academy of Management Journal 34 (3): 555-590.

Davenport, T. 1994. Saving IT's soul: Human-centered information management. Harvard Business Review 119: 27-33.

DeVellis, R. F. 1991. Scale Development. Newbury Park, NJ: Sage Publications.

Davenport, T. H., and L. Prusak. 1998. Working Knowledge: How Organizations Manage What They Know. Boston, MA: Harvard Business School Press.

Deal, T. E., and A. A. Kennedy. 2000. The New Corporate Cultures: Revitalizing the Workplace After Downsizing, Mergers and Reengineering. London-UK, TEXERE Publishing Limited.

Demarest, M. 1997. Understanding knowledge management. Long Range Planning 30 (3): 374-384.

Deshpande, R., J. U. Farley, and D. Bowman. 2004. Tigers, dragons, and others: Profiling high performance in Asian firms. Journal of International Marketing 12 (3): 5-29.

Dess, G. G., G. T. Lumpkin, and J. E. McGee. 1999. Linking corporate entrepreneurship to strategy, structure, and process: Suggested research directions. Entrepreneurship: Theory and Practice 23 (3): 85102.

DeTienne, K. B., G. Dyer, C. Hoopes, and S. Harris. 2004. Toward a model of effective knowledge management and directions for future research: Culture, leadership, and CKOs. Journal of Leadership and Organizational Studies 10 (4): 26-43.

Dillman, D. A. 2007. Mail and Internet Surveys: The Tailored Design Method. Hoboken, NJ: John Wiley and Sons.

Drucker. P. 1986. Innovation and Entrepreneurship. Harper and Row, New York, N.Y.

Earl, M. 2001. Knowledge management strategies: Toward taxonomy. Journal of Management Information Systems 18 (1): 215-223.

Eckhardt, J., and S. Shane. 2003. Opportunities and entrepreneurship. Journal of Management 29 (3): 333349 .

Elwany, M. H., and Z. Mahrous. 2016. Investigating knowledge management enablers affecting knowledge management success in Middle East and North Africa. Review of Contemporary Business Research 5 (1): 115-125. 
Eppler, M. J., and O. Sukowski. 2000. Managing team knowledge: Core processes, tools and enabling factors. European Management Journal 18 (3): 334-341.

Fahey, L., and L. Prusak. 1998. The eleven deadliest sins of knowledge management. California Management Review 40 (3): 265-276.

Foss, N. J., and T. Pedersen. 2002. Transferring knowledge in MNCs: The role of sources of subsidiary knowledge and organizational context. Journal of International Management 8 (1): 49-67.

Goffee, R., and G. Jones. 1996. What holds the modern company together? Harvard Business Review 74 (6): 133-148.

Gold, A. H., A. Malhotra, A. H. Segars. 2001. Knowledge management: An organizational capabilities perspective. Journal of Management Information Systems 18 (1): 185-214.

Grant, R. M. 1996. Toward a knowledge based theory of the firm. Strategic Management Journal 17: 109122.

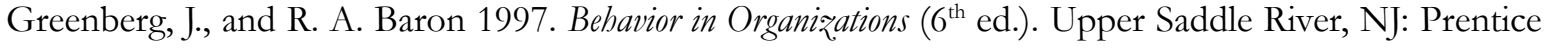
Hall.

Guadamillas, F., M. J. Donate, J. D. Sánchez de Pablo. 2008. Knowledge management for corporate entrepreneurship and growth: A case study. Knowledge and Process Management 15 (1): 32-44.

Hansen, M. T., and B. Oetinger. 2001. Introducing T-shaped managers: Knowledge management's next generation. Harvard Business Review (March): 107-116.

Hedlund, G. A. 1994. Model of knowledge management and the N-form corporation. Strategic Management Journal 15 (Summer) (Special Issue): 73-90.

Hill, J., C. Nancarrow, and L. T. Wright. 2002. Lifecycles and crisis point in SMEs: A case approach. Marketing Intelligence and Planning 20 (6): 361-9.

Hisrich, R. D., and M. P. Peters. 1986. Establishing a new business venture unit within a firm. Journal of Business Venturing 1 (3): 307-322.

Hitt, M. A., R. D. Ireland, S. M. Camp, D. L. Sexton. 2001. Strategic entrepreneurship: Entrepreneurial strategies for wealth creation. Strategic Management Journal 22 (6/7): 479-491.

Holsapple, C. W., and K. D. Joshi. 1999. Description and analysis of existing knowledge management frameworks. Proceedings of the 32nd Hawaii International Conference on System Sciences.

Holsapple, C. W., and K. D. Joshi. 2000. An investigation of factors that influence the management of knowledge in organizations. Journal of Strategic Information Systems 9 (2-3): 235-261.

Hornsby, J. S., and D. W. Naffziger. 1992. An interactive model of the corporate entrepreneurship process. Entrepreneurship: Theory and Practice 17 (2): 29-37.

Hornsby, J. S., D. F. Kuratko, and R. V. Montagno. 1999. Perceptions of internal factors for corporate entrepreneurship: A comparison of Canadian and U.S. managers. Entrepreneurship: Theory and Practice 24 (2): 9-24.

Hornsby, J. S., D. F. Kuratko, and S. A. Zahra. 2002. Middle managers' perception of the internal environment for corporate entrepreneurship: Assessing a measurement scale. Journal of Business Venturing 17 (3): 253-273.

Hornsby, J. S., D. F. Kuratko, D. A. Shepherd, J. P. Bott. 2009. Managers' corporate entrepreneurial actions: Examining perception and position. Journal of Business Venturing 24 (3): 236-247. 
Hughes, M., and R. E. Morgan. 2007. Deconstructing the relationship between entrepreneurial orientation and business performance at the embryonic stage of firm growth. Industrial Marketing Management 36 (5): 651-661.

Hurley, T. A., and C. W. Green. 2005. Knowledge management and the nonprofit industry: A within and between approach. Journal of Knowledge Management Practice 41 (2): 212 - 228

Ichijo, K, G. Krogh, and I. Nonaka. 1998. Knowledge enablers. In G. Krogh, J. Roos, and D. Kleine (Eds.), Knowing in Firms: 173-203. Thousand Oaks, CA: Sage Publications.

Ipe, M. 2003. Knowledge sharing in organizations: A Conceptual Framework. Human Resource Development Review 2 (4): 337-359.

Iqbal Shaikh, A. A., and U. S. Aktharsha. 2016. Dynamics of human resources management practices and knowledge management processes in service sector: An empirical study. The International Journal of Business and Management 4 (6): 64-77.

Ireland, R. D., and J. W. Webb. 2007. A cross disciplinary exploration of entrepreneurship research. Journal of Management 33 (6): 891-927.

Ireland, R. D., D. F. Kuratko, M. H. Morris. 2006. A health audit for corporate entrepreneurship: Innovation at all levels (Part 1). Journal of Business Strategy 27(1): 10-17.

Janz, B. D., and P. Prasarnphanich. 2003. Understanding the antecedents of effective knowledge management: The importance of a knowledge-centered culture. Decision Sciences 34 (2): 351-384.

Jarvenpaa, S. L., and D. S. Staples. 2000. The use of collaborative electronic media for information sharing: An exploratory study of determinants. Strategic Information Systems 9 (2/3): 129-154.

Jennings, D. F., and J. R. Lumpkin. 1989. Functionally modeling corporate entrepreneurship: An empirical integrative analysis. Journal of Management 15 (3): 485-502.

Jeong, I., J. H. Pae, and D. Zhou. 2006. Antecedents and consequences of the strategic orientations in new product development: The case of Chinese manufacturers. Industrial Marketing Management 35 (3): 348-358.

Jordan, J., and P. Jones. 1997. Assessing your company's knowledge management style. Long Range Planning 30 (3): 392-398.

Junnarkar, B. 1997. Leveraging collective intellect by building organizational capabilities. Expert Systems with Applications 13 (1): 29-40.

Kahn, K. B. 1996. Interdepartmental integration: A definition with implications for product development performance. Journal of Product Innovation Management 13: 137-151.

Kanter, R. M. 1982. The middle manager as innovator. Harvard Business Review 60 (4): 95-106.

Kanter, R. M. 1983. The Changemasters. New York, NY: Simon and Schuster.

Kanter, R. M. 1985. Supporting innovation and venture development in established companies. Journal of Business Venturing 1 (1): 47-60.

Kendall, K. E. 1997. The significance of information systems research on emerging technologies: Seven information technologies that promise to improve managerial effectiveness. Decision Sciences 28 (4): 775-792.

Kimberly, J.R. (1981). Managerial innovation, Handbook of Organizational Design (1): 84-104. New York: Oxford University Press. 
King, W. 1999. Integrating knowledge management into IS strategy. Information Systems Management 16 (4): 70-72.

Kohli, A. K., and B. J. Jaworski. 1990. Market orientation: The construct, research propositions, and managerial implications. Journal of Marketing 54 (2): 1-18.

Kor, Y. Y., J. T. Mahoney, and S. C. Michael. 2007. Resources, capabilities, and entrepreneurial perceptions. Journal of Management Studies 44 (7): 1187-1212.

Kreiser, P. M., L. D. Marino, and K. M. Weaver. 2002. Assessing the psychometric properties of the entrepreneurial orientation scale: A muti-country analysis. Entrepreneurship: Theory and Practice 26 (4): 71-92.

Krejcie, R. V., and D. W. Morgan. 1970. Determining sample size for research activities. Educational and Psychological Measurement 30: 607-610.

Kropp, F., N. J. Lindsay, and A. Shoham. 2006. Entrepreneurial, market, and learning orientations and international entrepreneurial business venture performance in South African firms. International Marketing Review 23 (5): 504-523.

Kuratko, D. F., R. V. Montagno, and J. S. Hornsby. 1990. Developing an intrapreneurial assessment instrument for effective corporate entrepreneurial environment. Strategic Management Journal 11 (5): 4958.

Kuratko, D. F., J. S. Hornsby, D. W. Naffziger, and R. V. Montagno. 1993. Implementing entrepreneurial thinking in established organizations. Advanced Management Journal 58 (1): 28-39.

Kuratko, D. F., R. D. Ireland, J. S. Hornsby. 2001. Improving ûrm performance through entrepreneurial actions: Acordia's corporate entrepreneurship strategy. Academy of Management Executive 15 (4): 6071.

Laupase, R. 2003. The Process of Converting Consultants' Tacit Knowledge to Organizational Explicit Knowledge: Case Studies in Management Consulting Firms. London: IRM Press.

Lee, H., and B. Choi. 2003. Knowledge management enablers, processes, and organizational performance: An integrative view and empirical examination. Journal of Management Information System 20 (1): 179-228.

Lee, J. H., and Y. G. Kim. 2001. Effects of managerial drivers and climate maturity on knowledge management performance: Empirical validation. Proceedings of Pacific Asia Conference on Information Systems: 1097-1111.

Leonard-Barton. D. A. 1995. Wellsprings of Knowledge: Building and Sustaining the Sources of Innovation. Boston: Harvard Business School Press.

Leonard, D., and S. Sensiper. 1998. The role of tacit knowledge in group innovation. California Management Review 40 (3): 112-132.

Li, Y., Y. Liu, and Y. Zhao. 2006. The role of market and entrepreneurship orientation and internal control in the new product development activities of Chinese firms. Industrial Marketing Management 35 (3): 336-347.

Liao, S. H., C. F. Wu, C. C. Chih. 2007. Knowledge sharing, absorptive capacity and innovation capability: An empirical study of Taiwan's knowledge intensive industries. Journal of Information Science 33:1-20.

Liebeskind, J. P. 1996. Knowledge, strategy, and the theory of the firm. Strategic Management Journal 17 (Winter): 93-107. 
Lin, H. F. 2007. Knowledge sharing and firm innovation capability: An empirical study. International Journal of Manpower 28: 315-332.

Lubit, R. 2001. Tacit knowledge and knowledge management: The keys to sustainable competitive advantage. Organizational Dynamics 29 (4): 164-178.

Lumpkin, G. T., and G. G. Dess. 1996. Clarifying the entrepreneurial orientation construct and linking it to performance. Academy of Management Executive 19 (1): 147-156.

Lumpkin, G. T., and G. G. Dess. 2001. Linking two dimensions of entrepreneurial orientation to firm performance: The moderating role of environment and industry life cycle. Journal of Business Venturing 16 (5): 429-451.

Madhavan, R., and R. Grover. 1998. From embedded knowledge to embodied knowledge: new product development as knowledge management. Journal of Marketing 62 (4): 1-12.

Mahoney, J. T. 1995. The management of resources and the resource of management. Journal of Business Research 33: 91-101.

Malhotra, A., and A. Majchrzak. 2004. Enabling knowledge creation in farflung teams: Best practices for it support and knowledge sharing. Journal of Knowledge Management 8 (4): 75-88.

March, J. G., and R. I. Sutton. 1997. Organizational performance as a dependent variable. Organization Science 8 (6): 698-709.

Martin, J. 1992. Cultures in Organizations: Three Perspectives. New York: Oxford University Press.

Marwick, A. D. 2001. Knowledge management technology. IBM Systems Journal 40 (4): 814-830.

Mavondo F., and M. Farell. 2004. Cultural orientation: Its relationship with market orientation, innovation and organizational performance. Management Decision 41(3): 241-249.

McKee, D. O., P. R. Varadarajan, and W. M. Pride. 1989. Strategic adaptability and firm performance: A market-contingent perspective. Journal of Marketing 53 (3): 21-35.

McKenna, R. 1999. New Management. Sydney: McGraw-Hill.

Menon, A., and R. Varadarajan. 1992. A model of marketing knowledge use within firms. Journal of Marketing 56 (4): 53-71.

Miller, D. 1983. The correlates of entrepreneurship in three types of firms. Management Science 29 (7): 770791.

Miller, D. 1987. Strategy making and structure: Analysis and implications for performance. Academy of Management Journal 30 (1): 7-32.

Morris, M. H., and D. F. Kuratko. 2002. Corporate Entrepreneurship. Orlando, Florida: Harcourt College Publishers.

Morrison, A. 2001. Entrepreneurs transcend time: A biographical analysis. Management Decision 39 (9): 784 91.

Naman, J. L., and D. P. Slevin. 1993. Entrepreneurship and the concept of fit: A model and empirical tests. Strategic Management Journal 14 (2): 137-153.

Ndlela, L. T., and A. S. A. Toit. 2001. Establishing a knowledge management programme for competitive advantage in an enterprise. International Journal of Information Management 21 (2): 151-165.

Neely, A. 1998. Measuring Business Performance. London: The Economist Books.

Nevis, E., A. Dibella, and J. Gould. 1995. Understanding organizations as learning systems. Sloan Management Review 36 (2): 73-85. 
Ngoc, P. T. B. 2005. An empirical study of knowledge transfer within knowledge-intensive firms in Vietnam. Proceeding of the Third International Conference on Management Education for 21 st Century - Management for the Knowledge Society. Hochiminh City, Vietnam on Sept., 8th-9th, 2005.

Nguyen, T. H., Q. Alam, and M. Perry. 2007. State versus market: The paradox of Vietnam's experience with SME. Proceeding of the 21t Australian and New Zealand Academy of Management Conference. Sydney, Australia.

Niaz Azari, K., and F. Amooei. 2008. Factors of knowledge management, Islamic Azad universities province. Journal of Knowledge and Educational Sciences Research 14: 93-106. Islamic Azad University.

Nonaka, I. 1990. Redundant, overlapping organization: A Japanese approach to managing the innovation process. California Management Review 32 (3): 27-38.

Nonaka, I. 1991. The knowledge-creating company. Harvard Business Review 96 (6): 96-104.

Nonaka, I., and H. Takeuchi. 1995. The Knowledge-Creating Company: How Japanese Companies Create the Dynamics of Innovation. New York, NY: Oxford University Press.

O’Dell, C., and C. Grayson. 1998. If only we knew what we know: Identification and transfer of internal best practices. California Management Review 40 (3): 154-174.

Pan, S., and H. Scarbrough. 1998. A socio-technical view of knowledge-sharing at Buckman laboratories. Journal of Knowledge Management 2 (1): 55-66.

Park, K. 2006. A review of the knowledge management model based on an empirical survey of Korean experts. Unpublished Doctoral Dissertation. University of Kyushu, Korea.

Pearce, J. A., T. R. Kramer, and D. K. Robbins. 1997. Effects of managers' entrepreneurial behavior on subordinates. Journal of Business Venturing 12 (2): 147-160.

Pennington, P. L. 2001. Leadership factors influencing team culture. Unpublished Doctoral Dissertation. Texas AandM University, College Station, TX.

Pentland, B. T. 1995. Information systems and organizational learning: The social epistemology of organizational knowledge systems. Accounting, Management and Information Technology 5 (1): 1-21.

Porter, M. E., and S. R. Whitcomb. 2003. The impact of contact type on Web survey response rates. Public Opinion Quarterly 67: 579-588.

Rahimi Rad, Z., A. Hedayati, B. Ghelichlee, and M. D. Roshan. 2016. Investigating in the relationship between knowledge management dimensions and the effectiveness of project management knowledge (Case Study: Tebyan Institute). International Business Management 10 (5): 638-645.

Raisinghani, M. 2000. Knowledge management: A cognitive perspective on business and education. American Business Review 18 (2): 105-112.

Raven, A., and S. G. Prasser. 1996. Information technology support for the creation and transfer of tacit knowledge in organizations. AIS 1996 Conference (http://hsb.baylor.edu/ramsower/ ais.ac.96/papers/RAVEN.htm).

Rea, L., and R. Parker. 2005. Designing and Conducting Survey Research: A Comprehensive Guide. San Francisco, CA: Jossey-Bass.

Riggins, F. J., and H. Rhee. 1999. Developing the learning network using extranets. International Journal of Electronic Commerce 4 (1): 65-83.

Robbin, S. P. 2004. Organizational Behavior (11 ${ }^{\text {th }}$ ed.). Upper Saddle River, NJ: Prentice-Hall.

Robinson, M. 2001. The ten commandments of intrapreneurs. New Zealand Management 48 (11): 95-98. 
Sabherwal, R., and I. Becerra-Fernandez. 2003. An empirical study of the effect of knowledge management processes at individual, group, and organizational levels. Decision Sciences 34 (2): 225-260.

Salvato, C. 2002. Antecedents of Entrepreneurship in Three Types of Family Firms. Jonkoping: Jonkoping International Business School.

Sathe, V. 1985. Managing an entrepreneurial dilemma: Nurturing entrepreneurship and control in large corporations. Frontiers of Entrepreneurship Research: 636-656. Wellesley, MA: Babson College.

Saunders, M., P. Lewis, and A. Thornhill. 2000. Research Methods for Business Students (2 ${ }^{\text {nd }}$ ed.). Hallow: Prentice Hall.

Sawhney, M., and E. Prandelli. 2000. Communities of creation: Managing distributed innovation in turbulent markets. California Management Review 42 (4): 24-54.

Schein, E. H. 2004. Organizational Culture and Leadership (3 ${ }^{\text {rd }}$ ed.). San Francisco: Jossey-Bass.

Schminke, M., M. L. Ambrose, and L. Cropanzano. 2000. The effect of organizational structure on perceptions of fairness. Journal of Applied Psychology 85: 294-304.

Segars, A. H., V. Grover, and J. T. C. Teng. 1998. Strategic information systems planning: Planning system dimensions, internal coalignment, and implications for planning effectiveness. Decision Sciences 29 (2): 303-345.

Seibert, S. E., M. L. Kraimer, and J. M. Crant. 2001. What do proactive people do? A longitudinal model linking proactive personality and career success. Personnel Psychology 54 (4): 845-874.

Shane, S., and S. Venkataraman. 2000. The promise of entrepreneurship as a field of research. Academy of Management Review 25 (1): 217-26.

Slevin, D. P., and J. G. Covin. 1990. Juggling entrepreneurial style and organizational structure - how to get your act together. Sloan Management Review (Winter): 43-53.

Slevin, D. P., and J. G. Covin. 1997. Time, growth, complexity and transitions: Entrepreneurial challenges for the future. Entrepreneurship: Theory and Practice 22 (2): 43-68.

Snow, C., and L. Hrebiniak. 1980. Strategy, distinctive competence, and organizational performance. Administrative Science Quarterly 25 (2): 317-336.

Song, M., F. Zhang, H. V. D. Bij, and M. Weggeman. 2001. Information Technology, Knowledge Processes and Innovation Success. Retrieved July 26, 2013, http://ideas.repec.org/p/dgr/tuecis/0107.html

Stevenson, H. H., and D. E. Gumpert. 1985. The heart of entrepreneurship. Harvard Business Review 85 (2): 85-94.

Stevenson, H. H., and J. C. Jarillo. 1989. A paradigm of entrepreneurship: Entrepreneurial management. Strategic Management Journal 11 (5): 17-27.

Stopford, J. M., and C. W. F. Baden-Fuller. 1994. Creating corporate entrepreneurship. Strategic Management Journal 15 (7): 521-536.

Stuart, R., and Abetti, P.A. (1987). Start-up ventures: Towards the prediction of initial success. Journal of Business Venturing, Vol. 2, pp. 215-230.

Sveiby, K. E. 1997. The New Organizational Wealth: Managing and Measuring Knowledge-Based Assets. Francisco, CA: Berrett-Koehler Publishers, Inc.

Syed-lkhsan, S. O. S., and F. Rowland. 2004. Knowledge management in a public organization: A study on the relationship between organizational elements and the Performance of knowledge transfer. Journal of Knowledge Management 8 (2): 95-111. 
Sykes, H. B., and Z. Block. 1989. Corporate venturing obstacles: sources and solutions. Journal of Business Venturing 4 (3): 159-167.

Sykes, H. B. 1992. Incentive compensation for corporate venture personnel. Journal of Business Venturing 7 (4): 253-265.

Szulanski, G. 1996. Exploring internal stickness: Impediments to the transfer of best practice within the firm. Strategic Management Journal 17 (10): 27-43.

Tata, J., and S. Prasad. 2004. Team self-management, organizational structure, and judgments of team effectiveness. Journal of Managerial Issues 16 (2): 248-265.

Teece, D. F. (1998). Capturing value from knowledge assets: The new economy, markets for knowhow and intangible assets. California Management Review 40 (3): 55-79.

Twomey, D. F., and D. L. Harris. 2000. From strategy to corporate outcomes: Aligning human resource management systems with entrepreneurial intent. International Journal of Commerce and Management 10 (3/4): 43-55.

Von Krogh, G. 1998. Care in knowledge creation. California Management Review 40 (3): 133-153.

Von Krogh, G., K. Ichijo, and I. Nonaka. 2000. Enabling Knowledge Creation: How to Unlock the Mystery of Tacit Knowledge and Release the Power of Innovation. Oxford University Press, New York, N.Y.

Von Krogh, G., I. Nonaka, and M. Aben. 2001. Making the most of your company's knowledge: a strategic framework. Long Range Planning 34 (4): 421-39.

Walsh, J. P., and G. R. Ungson. 1991. Organizational memory. Academy of Management Review 16 (1): 57-91.

Waseem Bari, M., M. Fanchen, and M. Awais Baloch. 2016. The relationship between knowledge management practices, innovativeness and organizational performance (A Case from Software Industry). Science International (Lahore) 28 (1): 463-475.

West, D., and P. Berthon. 1997. Antecedents of risk-taking behavior by advertisers: Empirical evidence and management implications. Journal of Advertising Research 37 (5): 27-40.

Wiig, K. M. 1994. Knowledge Management Foundations: Tbinking about Tbinking-How People and Organizations Create, Represent, and Use Knowledge. Arlington, TX: Schema Press.

Wijnhoven, F. 1998. Designing organizational memories: Concept and method. Journal of Organizational Computing and Electronic Commerce 18 (1): 29-55.

Wiklund, J., and D. Shepherd. 2003. Knowledge-based resources, entrepreneurial orientation and the performance of small and medium-sized businesses. Strategic Management Journal 24 (13); 13071314.

Wiklund, J., and D. Shepherd. 2005. Entrepreneurial orientation and small business performance: A configurational approach. Journal of Business Venturing 20 (1): 71-91.

Wolfer, L. 2007. Real Research: Conducting and Evaluating Research in the Social Sciences. Boston: Pearson/Allyn and Bacon.

Woodman, R., J. Sawyer, and R. Griffin. 1993. Toward a theory of organizational creativity. Academy of Management Review 18 (2): 293-321.

Zack, M. 1999. Managing codified knowledge. Sloan Management Review 40 (4): 45-57.

Zaheer, A, K. U. Rehman, and M. A. Khan. 2010. Development and testing of a business process orientation model to improve employee and organizational performance. African Journal of Business Management 4 (2): 149-161. 
Zahra, S. A. 1991. Predictors and financial outcomes of corporate entrepreneurship: An exploratory study. Journal of Business Venturing 6 (4): 259-285.

Zahra, S. A. 1993. Environment, corporate entrepreneurship, and financial performance: A taxonomic approach. Journal of Business Venturing 8 (4); 319-340.

Zahra, S. A., and J. G. Covin. 1995. Contextual influence on the corporate entrepreneurship-performance relationship: A longitudinal analysis. Journal of Business Venturing 10 (1): 43-58.

Zahra, S. A., and A. P. Nielsen. 2002. Sources of capabilities, integration and technology commercialization. Strategic Management Journal 22: 377-398. 


\section{Appendix}

\section{Test Instruments}

\section{Knowledge Management Enablers}

My organization provides information technology support for collaborative work regardless of the time and place.

My organization provides information technology support for communication among the organization's employees.

My organization provides information technology support for searching and accessing the necessary information.

My organization provides information technology support for simulation and prediction.

My organization provides information technology support for systematic storing.

I can take action without a superior.

I am encouraged to make my own decisions.

I do not need to refer to someone else to make decisions.

I do not need to ask my superior before taking action.

I can make decisions without approval.

In my organization, there are many activities that are covered by formal procedures.

In my organization, contact with my organization is on a formal or planned basis.

In my organization, rules and procedures are typically written.

In my organization, I cannot ignore the rules and reach informal agreements to handle some situations.

In my organization, I cannot make my own rules on the job.

I am satisfied with the amount of collaboration.

My colleagues are supportive.

My colleagues are helpful.

There is a willingness to collaborate across the organizational units within my organization.

There is a willingness within my organization to accept responsibility for failure.

I am generally trustworthy.

I have mutual faith in the other members' intentions and behavior.

I have mutual faith in the others' ability.

I have mutual faith in the others' commitment to organizational goals. 
I have mutual faith in the others' commitment to the company as a whole.

I have relationships based on mutual faith.

Organizational Characteristics

It is basically my own responsibility to decide how my job gets done.

I have the freedom to decide what I do in my job.

I almost always get to decide what I do in my job.

I have much autonomy in my job and am left on my own to do my own work.

I am provided with the freedom to use my own judgment.

I feel that I am my own boss and do not have to double-check all of my decisions with someone else.

I have a lot of variety in how I carry out my daily work.

I have just the right amount of time, resources and workload to do everything well.

I always have plenty of time and resources to get everything done.

I feel that I am always working with time and resource constraints in my job.

My co-workers and I always find the time and resources for long term problem solving.

During the past three months, my workload kept me from spending time developing new ideas.

This organization supports many small and experimental projects.

Employees are often encouraged to take calculated risks with ideas as long as the organizational priorities are not compromised.

Managers encourage innovators to bend the rules and rigid procedures in order to keep promising ideas on track.

Employees are encouraged to talk to employees in other departments of the organization about ideas for new projects.

Money is often available to get new ideas off the ground.

My superior will give me special recognition if my work performance is especially good.

My superior will tell his/her boss if my work was outstanding.

The rewards I receive are dependent upon my work.

My organization has a standardized reward system for sharing knowledge.

\section{Entrepreneurial Orientation}

I participate in discussions regarding improvements at work.

I discuss improvements at work with my colleagues. 
I like to work with issues related to improvements at work.

I create new ideas for difficult issues I encounter at work.

I search out new working methods, techniques, or instruments for problems.

I am able to generate original solutions to problems I encounter at work.

I seek support from others for my innovative ideas.

I seek approval for my innovative ideas to be used at work.

My ideas have been implemented at my work.

I get management excited about my ideas.

I am encouraged to undertake high-risk projects.

I can adopt a bold, aggressive stance when confronted with decision-making situations involving uncertainty, to maximize potential.

I am encouraged to explore new opportunities gradually via cautious behavior.

I am constantly on the lookout for new ways to improve my life.

Wherever I have been, I have been a powerful force for constructive change.

Nothing is more exciting than seeing my ideas turn into reality.

If I see something I don't like, I fix it.

No matter the odds, if I believe in something I will make it happen.

I love being a champion for my ideas, even against other people's opposition.

I excel at identifying opportunities.

I am always looking for better ways to do things.

If I believe in an idea, no obstacle will prevent me from making it happen.

I can spot a good opportunity long before others can. 